\title{
THE LIMITED SIGNIFICANCE OF NORMS \\ FOR CORPORATE GOVERNANCE
}

\section{MARCEL KAHAN ${ }^{\dagger}$}

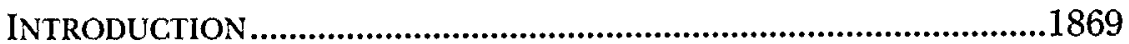

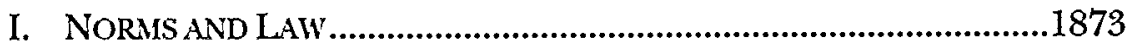

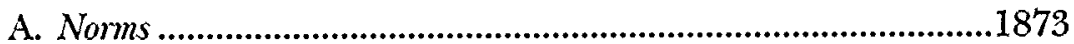

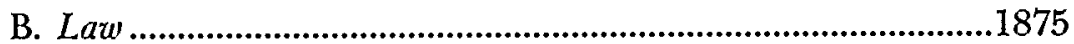

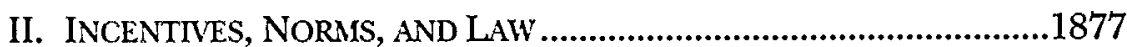

A. Compensation-Related Incentives..................................................1879

B. Job-Preservation-Related Incentives................................................1879

C. Liability-Regime-Related Incentives.............................................1880

D. Future-Employment-Related Incentives...........................................1880

E. Social-Status-Related Incentives................................................1881

F. Internalized Incentives (a.k.a. Preferences)...................................1881

III. NORMSS AND CORPORATE POWERS.............................................1882

A. Executive Compensation ..........................................................1883

1. The Level of Executive Compensation .............................1884

2. The Use of Stock Options.................................................1888

3. Norms and Executive Compensation...............................1890

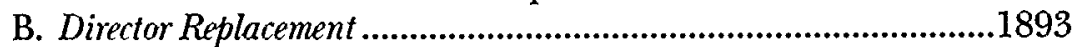

IV. NORMS AND EXTERNAL INCENTIVES..........................................1895

A. Social-Status-Related Incentives.................................................1896

B. Intermalized Incentives..........................................................1897

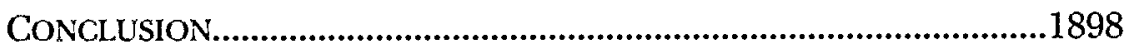

\section{INTRODUCTION}

In organizing a symposium on norms and corporate law, one makes an implicit claim that the concept of norms is significant to our understanding of corporate law and the problems corporate law is meant to address. Unsurprisingly, the main organizers of this Symposium, Professors Rock and Wachter, advance the thesis that firms

$†$ Professor of Law, New York University School of Law. I would like to thank Jennifer Arlen, Lucian Bebchuk, Henry Hansmann, Ehud Kamar, Mike Klausner, Jody Kraus, Paul Mahoney, Ed Rock, and the participants in the Symposium on Norms and Corporate Law at the University of Pennsylvania Law School for comments and the Filomen D'Agostino and Max E. Greenberg Research Fund for financial assistance. 
are largely governed by norms, and not by law. ${ }^{1}$

I am more skeptical about the relevance of norms to corporate law. Partly, my skepticism is related to the very concept of norms as used in the "law and norms" literature. Most contributors to that literature have their own (often itself ambiguous) definition of "norms," and many bemoan the fact that no agreed-upon definition of the term exists." For example, Robert Ellickson, one of the norms pioneers, defines norms as rules that emanate from social forces, distinguishing them from personal ethics (internalized rules), contracts (rules imposed by second-party controllers), rules imposed by organizations, and laws (rules imposed by governments). ${ }^{3}$ Eric Posner, in a contribution to an earlier symposium on norms, defines norms as rules that distinguish "desirable and undesirable behavior" and give "a third party the authority to punish a person who engages in the undesirable behavior." Richard McAdams notes that norms refer to "informal social regularities that individuals feel obligated to follow because of an internalized sense of duty, because of a fear of external nonlegal sanctions, or both." "F For Bob Cooter, by contrast,

${ }^{1}$ Edward B. Rock \& Michael L. Wachter, Islands of Conscious Power: Law, Norms, and the Self-Governing Corporation 149 U. PA. L. REV. 1619 (2001); see also Margaret M. Blair \& Lynn A. Stout, Trust, Trustworthiness, and the Behavioral Foundations of Corporate Law, 149 U. PA. L. REv. 1735, 1738 (2001) (arguing that "internalized trust and trustworthiness play important roles in discouraging opportunistic behavior among corporate participants" (emphasis omitted)); Robert Cooter \& Melvin A. Eisenberg, Faimess, Character, and Efficiency in Firms, 149 U. PA. L. REv. 1717, 1717 (2001) (advancing the thesis that "firm-specific fairness norms typically promote efficiency" and that "firm-specific fairness norms best promote efficiency when supported by reputation effects and when the firm's agents internalize the norms"); Saul Levmore, Puzzling Stock Options and Compensation Norms, 149 U. PA. L. REv. 1901, 1936-39 (2001) (arguing that norms regarding nonconflicting fortunes partially explain the prevalence of nonindexed options); David A. Skeel, Jr., Shaming in Corporate Law, 149 U. PA. L. REV. 1811, 1820-23 (2001) (arguing that norms-related shaming sanctions are important in the corporate context).

${ }^{2}$ See, e.g., David Charny, Illusions of a Spontaneous Order: "Norms" in Contractual Relationships, 144 U. PA. L. REV. 1841, 1845 (1996) ("[O]ne might question whether it is useful to use the same term ('norms') for comprehensive and relatively complex regimes as for more informal and diffuse sanctioning systems."); Richard H. McAdams, The Origin, Development, and Regulation of Norms, 96 MICH. L. REV. 338, 342 (1997) (noting "fundamental ambiguities in the term norm" that give the law and norms literature "an unnecessarily ad hoc appearance" (emphasis omitted)); Eric A. Posner, Law, Economics, and Inefficient Norms, 144 U. PA. L. REV. 1697, 1699 (1996) ("The concept of a 'norm' is slippery, and scholars use it in different ways.").

3 ROBERT C. ElLICKSON, ORdER WITHOUT LAW: HOW NeIGHBORS SETtLE DISPUTES 125-27 (1991).

* Posner, supra note 2, at 1699.

${ }^{5}$ McAdams, supra note 2, at 340. 
internalization by a large group of people is a necessary prerequisite for a norm." Richard Posner and Eric Rasmusen regard as norms any social rule "that does not depend on government for either promulgation or enforcement." Striking a similar vein, Ed Rock and Mike Wachter, in their invitation for and contribution to this Symposium, explain that norms mean "nonlegally enforceable rules and standards." For Mel Eisenberg, norms include any behavioral patterns, regardless of whether they entail a sense of obligation and regardless of whether they are self-consciously adhered to. ${ }^{9}$

Since there appears to be no norm for the definition of "norms," the "norms" terminology does not add much conceptual clarity. Possibly, "law and normers" would be better off by jettisoning the term "norm" and instead using a set of different terms." (The persistence of the "norms" terminology despite its conceptual ambiguity, however, suggests that "law and normers" obtain reputational or psychic benefits from participating in a "law and norms" movement.) In this respect, Rock and Wachter deserve applause for using the precise (if inelegant) acronym of NLERS to denote their concept of norms."

My skepticism about the relevance of norms to corporate law, however, extends beyond the conceptual ambiguity of the term. Even well-defined renditions of the norms concept suffer from one of two shortcomings. In their wider definitions, "norms" include phenomena that are so heterogeneous that the term "norms" does not add a useful conceptual tool to their analysis. In particular, many of these wider definitions encompass socially created or enforced incentives as well as market-created structures that have long been analyzed in the traditional economics literature. In the narrower definitions, by contrast, norms tend to be only of limited significance for corporate governance.

'Ste' Robert D. Cooter, Decentralized Law for a Complex Economy: The Structural Approach to Adjudicating the Law Merchant, 144 U. PA. L. REv. 1643, 1661-66 (1996) (noting that a social norm exists if enough people have internalized a sense of obligation and the resulting threat of criticism and punishment deters violation by others).

${ }_{7}$ Richard A. Posner \& Eric B. Rasmusen, Creating and Enforcing Norms, with Special Referente' to Santions, 19 INT'L REv, I. \& ECON. 369, 369 (1999).

Rock \& Wachter, supra note 1, at 1623.

"Melvin A. Eisenberg, Comporate Law and Sacial Norms, 99 ColuM. L. REV. 1253, 125657 (1999).

1" Here are a few suggestions, some of which are already employed to denote specific subcategories of norms: tastes, ethics, habits, practices, ideologies, belief systems, social obligations, and NLERS (nonlegally enforceable rules and standards).

"Rock \& Wachter, supra note 1, at 1641. 
Let me qualify my latter argument by stressing that it is contextspecific. It is confined to the significance of norms in the "internal affairs" of a public corporation-that is, to the relationship between shareholders and managers-in the present-day United States. "Norms" may well be important in other contexts, such as property disputes in Shasta County, ${ }^{12}$ labor relations, ${ }^{13}$ safe sex education, ${ }^{14}$ or economic transitions, ${ }^{15}$ to corporate law in other countries, ${ }^{16}$ or even to relations within closely held companies in the United States. But for an understanding of the internal affairs of present-day, U.S. public companies, norms have only a limited significance.

In Part I of this Article, I present a working definition of norms and sketch the role of law in the corporate structure. My definition of norms encompasses rules, other than legal duties, that are regularly followed due to either an external "punitive" sanction administered by a third party or a related internalized sense of obligation. Corporate law regulates the internal affairs of a corporation primarily by establishing a system of powers and only to a lesser extent by creating a system of duties. Necessarily, therefore, nonlegal factors (including, possibly, norms) affect how these powers are exercised.

Part II presents a framework for analyzing the role of norms in corporate governance. The principal structural aim of corporate law is the effective regulation of centralized management. Since centralized management is easily established-by giving a board of directors broad powers to act-the main focus of corporate governance is to establish an incentive structure bearing on corporate managers that assures that managers act in the interest of shareholders. In Part II, I identify six categories of this incentive scheme. The first three categories of incentives-compensationrelated, job-preservation-related, and liability-regime-related-derive

${ }^{12}$ See ELIICKSON, supra note 3.

${ }^{13}$ See Edward B. Rock \& Michael L. Wachter, The Enforceability of Norms and the Employment Relationship, 144 U. PA. L. REv. 1913 (1996).

${ }^{14}$ See Lawrence Lessig, The Regulation of Social Meaning, 62 U. CHI. L. REv. 943, 1019-25 (1995) (examining the regulation of dangerous sex in the context of "social meaning regulation").

${ }^{15}$ See Richard H. Pildes, The Destruction of Social Capital Through Law, 144 U. PA. L. REV. 2055, 2062-63 (1996) (noting the relationship between background social norms and successful economic systems).

${ }^{16}$ See, e.g., Thomas J. André, Jr., Cultural Hegemony: The Exportation of Anglo-Saxon Corporate Governance Ideologies to Germany, 73 TUL. L. REV. 69, 104-16 (1998) (suggesting that cultural factors account for the German governance model); id. at 121-22 (mentioning the common claim that German business ethics are incompatible with hostile takeovers). 
from the powers and rights established by corporate law. The latter three categories of incentives-future-employment-related, socialstatus-related, and internalized-are external to corporate law. Norms potentially affect incentives in four of these categories: compensation, job preservation, social status, and internalized incentives.

Part III considers the significance of norms for compensation and job-preservation-related incentives. With respect to executive compensation, I conclude that although its structure is principally driven by economic and regulatory factors, norms may have a limited influence. With respect to director replacement, however, norms play no material role.

Part IV examines the relation between norms and social-statusrelated and internalized incentives. Although norms may well be significant to social-status-related incentives, these incentives do not have a substantial impact on managerial agency costs. With respect to internalized incentives, I suggest that the key factor is the economic process of managerial selection, which results in the promotion of managers who have internalized beneficial norms, rather than the existence of norms that are specifically managerial.

\section{NORMS AND LAW}

\section{A. Norms}

The plethora of definitions of "norms" is troubling in several respects. To begin with, it is obviously difficult to discuss a concept if that concept has no well-defined content. Moreover, the definitions of "norms" exhibit an imperialistic trend, having expanded over time from a relatively narrow set to include virtually everything other than law. Evidencing this expansion, for example, Mel Eisenberg has recently defined social norms to encompass "all rules and regularities concerning human conduct, other than legal rules and organizational rules." ${ }^{17}$

Perhaps the most problematic aspect of the definitions of "norms," however, is that the wider definitions include under the norms umbrella dissimilar incentive structures, some of which are well-defined and analyzed outside the "law and norms" literature. Under many of these wider definitions, any type of rule ("you

${ }^{17}$ Eisenberg, supra note 9, at 1255 (emphasis added). 
shall ..." or "you shall not...") governing how to conduct oneself, which is regularly followed by at least a relevant subset of actors and which is not a command of law, is a norm. This set, however, includes rules that are followed because they are internalized and rules that are followed because of external (nonlegal) sanctions (with sanctions referring to both a negative sanction-punishment-and a positive one-reward). It includes rules that are enforced by second-party sanctions (that is, sanctions administered by the party who suffers from the rules violation) and rules that are enforced by third-party sanctions (that is, sanctions administered by a person other than the party who suffers from the rules violation). And it includes rules in which enforcement is motivated by self-protection and rules in which enforcement is intended to punish the rule-violator (or reward the rule-abider).

For example, a small-town grocery store may not sell low-quality produce because the owner takes pride in the quality of the food she sells (internalized rule) or because her customers would buy fewer goods (external sanction). In the latter case, the owner may fear that customers who bought low-quality produce will take their business to another store (second-party enforced) or tell their friends, who will then take their business to another store (third-party enforced). Customers who take their business to a different store may do so because they want to avoid buying low-quality produce in the future (self-protective enforcement) or out of resentment for how their friends were treated when they last bought produce at that store (punitive enforcement).

I regard these distinctions as important because second-party and third-party self-protective enforcement are primarily economic in character. ${ }^{18}$ Such enforcement can be, and long has been, analyzed using traditional economic tools and neither requires nor benefits from being lumped under the heading of "norms."

${ }^{18}$ Even punitive second-party enforcement can be part of an economically motivated reputational strategy.

${ }^{19}$ For economic analysis of the concept of reputation, which is related to selfprotective enforcement, see, for example, Pierpaolo Battigalli \& Joel Watson, On "Reputation" Refinements with Heterogeneous Beliefs, 65 ECONOMETRICA 369 (1997); Marco Celentani et al., Maintaining a Reputation Against a Long-Lived Opponent, 64 ECONOMETRICA 691 (1996); Benjamin Klein \& Keith B. Leffler, The Role of Market Forces in Assuring Contractual Perjormance, 89 J. POL. ECON. 615 (1981); David M. Kreps \& Robert Wilson, Reputation and Imperfect Information, 27 J. ECON. THEORY 253 (1982); Paul Milgrom \& John Roberts, Predation, Reputation, and Entry Deterrence, $27 \mathrm{~J}$. EcoN. THEORY 280 (1982); Carl Shapiro, Consumer Information, Product Quality, and Seller Reputation, 13 BELL J. ECON. 20 (1982); Carl Shapiro, Premiums for High Quality Products 
For purposes of this Article, I therefore define "norms" to include only rules of conduct, other than legal commands, that are regularly followed and that are sanctioned by punitive third-party enforcement, as well as internalized rules that correspond to such third-partyenforced rules. This definition includes most incentive structures that are not economic or legal in character. And even though it lumps together two distinct enforcement mechanisms, internalized rules and punitive third-party-enforced rules with the same content are arguably mutually reinforcing to such a high degree that separating these mechanisms would not be useful.

\section{B. Law}

As norms exclude legal commands, it is helpful next to examine the rules of corporate law. To lend some greater precision to this endeavor, I will employ Hohfeldian terminology. ${ }^{20}$ Hohfeld distinguishes among four basic types of legal entitlements (with four correlative encumbrances): rights, privileges, powers, and immunities. Rights and privileges refer to static relations. $X$ has a right as regards $Y$ with respect to an action if $Y$ violates a correlative duty if she takes the action. $X$ has a privilege as regards $Y$ with respect to an action if $X$ may take the action (with $Y$ having a no-right). For example, $X$ has a right that $Y$ not enter $X$ 's property and a privilege to enter her own property. $Y$ has a duty not to enter $X$ 's property and a no-right to stop $X$ from entering $X$ 's property. ${ }^{21}$

Powers and immunities refer to dynamic relations. A power connotes the ability, through one's volitional act, to change a legal relation. If $Y$ offers to buy $X$ 's property, for example, $X$ obtains the power to accept $Y$ 's offer (and thereby give $Y$ a right to have $X$ perform) and $Y$ becomes subject to a corresponding liability. And unless $X$ has offered to sell her property to $Y, X$ has an immunity and $Y$ a correlative disability with respect to such a sale. ${ }^{22}$

Hohfeld thus clarifies that law extends far beyond creating rights: "One of the greatest hindrances to the clear understanding, the incisive statement, and the true solution of legal problems frequently

as Retums to Reputations, 98 Q.J. ECON. 659 (1983); Steven Tadelis, What's in a Name?: Reputation as a Tradeable Asset, 89 AM. ECON. REV. 548 (1999).

Sir Wesley N. Hohfeld, Some Fundamental Legal Conceptions as Applied in Judicial Reasoning, 23 YALE L.J. 16 (1913).

Id at $30-44$.

2 Id. at $44-58$. 
arises from the express or tacit assumption that all legal relations may be reduced to 'rights' and 'duties' ...., ${ }^{, 23}$ To the extent that some law and normers have made this assumption, they have understated the significance of law. ${ }^{24}$

Turning to corporate law, the corporate form creates, in Hohfeldian terms, the following three principal legal relations. First, it vests in the directors powers with respect to the corporate property in relation to third parties, such as the power to accept an offer by a third party to purchase the property. ${ }^{25}$ Second, it vests in shareholders the power to replace the directors, as well as some governance powers, such as the power to change the by-laws or to approve a charter amendment or merger proposed by the directors. ${ }^{26}$ Third, it vests in shareholders rights vis-à-vis the directors and imposes correlative fiduciary and statutory duties on the directors. ${ }^{27}$

This description is, of course, highly simplified. It leaves out many important details and important features, such as limited liability-a Hohfeldian no-right by corporate creditors to seek payment from shareholders-that do not relate to the internal affairs of a corporation. ${ }^{28}$ To some extent, these omissions are addressed later in this Article. At this point, however, I would like to make two observations.

First, the creation of powers is a crucial formal feature of the corporate form. The corporate form establishes the powers of directors over corporate property and the power of shareholders to replace directors. As the Hohfeldian distinction between rights and powers highlights, powers contain an inherent discretionary element, the exercise of which is not governed by law. ${ }^{29}$ When law confers a

${ }^{23} I d$. at 28.

${ }^{24}$ See, e.g., ELLICKSON, supra note 3, at 127 (suggesting that laws are sanctiontriggering rules enforced by the state).

${ }^{25}$ See, e.g., DEL. CODE ANN. tit. 8, § 141 (a) (1991) ("The business and affairs of every corporation... shall be managed by or under the direction of a board of directors....").

${ }^{26}$ See, e.g., id. $\$ 141(\mathrm{k})$ (allowing for the removal of directors); id. $\$ 211(\mathrm{~b})$ (providing for the election of directors).

${ }^{27}$ See, e.g., id. $\$ \$ 219-220$ (providing for information rights of shareholders); Aronson v. Lewis, 473 A.2d 805, 811 (Del. 1984) (indicating that directors owe fiduciary duties to shareholders).

${ }^{28}$ Limited liability is, for shareholders of nonpublic companies, probably an important benefit to incorporating. ROBERT C. CLARK, CORPORATE LAW \$ 1.2.1 (1986).

${ }^{29}$ See, e.g., Hohfeld, supra note 20, at 21-25 (discussing the variant concepts of legal interests and legal powers). 
power, law does not thereby prescribe how this power is to be exercised." This implies that when a power is or is not exercised, the law that established the power and something else that determines its use necessarily interact. One issue I will address is whether this "something else" can be profitably categorized as norms."

Second, the three principal legal relations created by the corporate form are substantively linked as they all concern the regulation of centralized management. By obtaining powers over the corporate property, directors have the legal ability to run the corporation's affairs. This power can be regulated by circumscribing its extent (through direct limits on directors' powers), by circumscribing the manner in which it is exercised (through duties), and by preserving shareholders' options to override specific decisions or to divest certain directors of their power altogether (through shareholder governance powers and their power to elect directors). The main aim of these legal rules, and the ultimate issue in structuring a public corporation, is to give managers the ability and the incentives to run the company in the interests of the shareholders. ${ }^{32}$ Another issue I will address is whether norms play a significant role in this scheme.

\section{INCENTIVES, NORMS, AND LAW}

The effective management of a public corporation requires the separation of ownership and control. Multiple, dispersed shareholders cannot themselves make the many day-to-day management decisions that it takes to run a public company. The corporate form solves this problem by delegating the power to manage the company to the board of directors, which further delegates the power to the corporate officers. ${ }^{34}$

The resulting separation of ownership and control, however, creates an agency problem: since managers do not owm all of the corporation's equity-indeed, they often own only a trivial portion-

"* This is also true for rights. The law may give you a right, but it does not tell you whether you should enforce it or not. If one takes into account that rights are not automatically enforced, actions that infringe on a Hohfeldian right ( $Y$ stepping on $X$ s property) really confer a Hohfeldian power ( $X$ may elect to obtain damages from $Y$ ).

See infra Part III.

sis See, e.g., Rock \& Wachter, supra note 1.

See infra Part III.

${ }^{34}$ Jeffrey N. Gordon, Shareholder Initiative: A Social Choice and Game Theoretic Approach to Corporate Law, 60 U. CNN. L. REV. 347, 353-54 (1991). 
their interests diverge from those of the shareholders as a group. The main issue in corporate governance is therefore to create incentives for managers to run the company in the interest of shareholders. I will refer to managers who run the company in this fashion as "well-performing" or "high-quality" managers and executives.

The incentive structure that affects how well a manager will perform is complex. In this Part, I first classify the incentives into six substantive categories. The first three categories include incentives that are internal to corporate law: incentives related to compensation, job preservation, and the corporate liability regime. The remaining three categories include incentives that are largely external to corporate law: incentives related to future employment, social status, and internalized incentives. ${ }^{36}$

${ }^{35}$ Unlike principals in a standard agency relationship, shareholders of a corporation cannot themselves exercise power over the property of a corporation or give their agents binding directions on how to exercise such powers. This lack of shareholder powers is not a necessary consequence of granting operational powers to the board (centralized management). Even if the board has operational powers, shareholders could retain the power to give operational directions to the directors. In fact, the board of directors generally delegates its day-by-day operational powers to the corporate officers, but nevertheless retains the power to give directions to the officers. $I d$. at 354 (noting that the typical delegation of power is not absolute). Although there are various theories that may justify the fact that shareholders lack the power to give operational directions to the board, see, e.g., id. at 359-63 (suggesting that one problem of shareholder voting is "cycling"), in my view, the lack of shareholder operational powers is largely trivial and, to the extent it matters, probably inefficient. Even if shareholders had the power to make operational decisions, this power would rarely be exercised. Running a company takes information, expertise, and the ability to react quickly to developments; it is a task for which dispersed shareholders are ill-suited. Being rationally aware of their own limitations, shareholders will generally leave the job of running the company's operations to the professional managers. More important than the lack of operational powers are the limits on shareholder governance powers. Shareholders, for example, cannot, without board approval, change governance provisions in the certificate of incorporation, see DEL. CODE ANN. tit. 8, § 242(b) (1) (1991 \& Supp. 2000) (requiring board approval for charter amendments), or reincorporate the corporation into a different state, see id. $\$ 251$ (b) (requiring board approval for a merger). Possessing such governance powers would be useful for shareholders. Cf. Lucian A. Bebchuk, Reconsidering the Allocation of Power Between Managers and Shareholder (Apr. 3, 2001) (unpublished manuscript, on file with author) (arguing that shareholders should have the power to change the charter or reincorporate without board approval).

${ }^{36}$ The principal incentive structure discussed here is the one bearing on managers who make operational decisions. Other pertinent incentive structures include the ones bearing on outside directors and on shareholders with respect to governance decisions that in turn affect the incentive structure bearing on managersfor example, decisions to set the compensation scheme or to oust managers. These latter structures are discussed in the context of managers' incentives. 


\section{A. Compensation-Related Incentives}

The compensation structure for managers can provide them with important incentives. If well-performing managers receive greater compensation than non-well-performing managers, incentives for high-quality management are enhanced. On the other hand, compensation can also create "perverse" incentives to perform less well-for example, by rewarding managers who engage in expansions and diversification that reduce company value. ${ }^{37}$

Compensation-related incentives can be created through a plan that promises greater benefits to managers who perform in a certain manner. In the United States, such incentive compensation plans usually take the form of bonus plans, in which managers are promised a certain extra payment if they meet specified performance targets (thus creating incentives to meet these targets), ${ }^{38}$ or stock option plans, in which managers are awarded stock options or similar financial products that increase in value as the company's stock price increases (thus creating incentives to increase the company's stock price). In addition to these plans, the possibility that well-performing managers will receive future raises in their compensation can provide incentives for high-quality management.

\section{B. Job-Preservation-Related Incentives}

The desire of managers to retain their jobs, or, at least, not be forced to depart, is another important element in the incentive structure. $^{\text {al }}$ If bad performance leads to a higher probability of a forced departure, managers will have incentives to perform well.

Corporate law provides several mechanisms by which managers

${ }^{17}$ See, e.g., Patricia M. Dechow \& Richard G. Sloan, Executive Incentives and the Horizon Problem, 14 J. ACCT. \& ECON. 51, 55 (1991) (noting that accounting-based bonus plans may create perverse incentives to reduce research and development expenditures).

i* See Susan J. Stabile, Motivating Executives: Does Performance-Based Compensation Positively Affect Managerial Performance?t, 2 U. PA. J. LAB. \& EMP. L. 227, 234-35 (1999) (describing bonus plans).

${ }^{34}$ See infra Part III.A.2.

"See Tod Perry \& Marc Zenner, CEO Compensation in the 1990s: Shareholder Altgnment or Shareholder Expropriation?, 35 WAKE FOREST L. REV. 123, 138-39 (2000) (adducing evidence that salaries are increased at well-performing firms, but not lowered at poorly performing firms).

"See Jerold B. Warner \& Ross L. Watts, Stock Prices and Top Management Changes, 20 J. FIN. ECON. 461 (1988) (finding an inverse relation between the probability of a management change and a firm's share performance). 
can be ousted. Shareholders can precipitate an ouster through a traditional proxy contest in which they elect a rival management team. ${ }^{42}$ A raider can acquire the company and fire managers. ${ }^{43}$ Or outside directors, prompted by shareholders or on their own initiative, can oust the incumbent managers."

Here, as well, it is conceivable that incentives may be perverse. If, for example, the stock of companies run by well-performing managers who invest in long-term projects is systematically undervalued, the fact that such companies may become attractive takeover targets could create incentives against value-enhancing, long-term investments. ${ }^{\text {t. }}$

\section{G. Liability-Regime-Related Incentives}

Corporate law imposes on managers the fiduciary duties of loyalty and care as well as other statutory obligations. ${ }^{46}$ If managers violate their duties, shareholders can enforce their rights through a lawsuit, resulting in potential monetary liability and other unpleasantries. Managers thus have incentives to comply with their duties. Moreover, to the extent that the scope of management's duties is uncertain or such duties are imperfectly enforced, managers have incentives to avoid taking actions that, while in fact not violating their duties, entail the risk of a lawsuit. ${ }^{47}$

\section{Future-Employment-Related Incentives}

Another reason why a manager may perform well is that she is concerned about her future employment opportunities. ${ }^{48}$ Even a well-

${ }^{42}$ See, e.g., David Ikenberry \& Josef Lakonishok, Corporate Governance Through the Proxy Contest: Evidence and Implications, $66 \mathrm{~J}$. Bus. 405, 417-21 (1993) (examining the relationship between performance and incidence of proxy contests).

${ }^{43}$ See infra Part III.B.

${ }^{44}$ See, e.g., Michael S. Weisbach, Outside Directors and CEO Turnover, $20 \mathrm{~J}$. FIN. ECON. 431, 453 (1988) (finding a stronger association between prior performance and probability of a resignation for companies with outsider-dominated boards than for companies with insider-dominated boards). See generally Perry \& Zenner, supra note 40 , at 134-35 (reviewing studies linking performance and tenure).

${ }^{45}$ See, e.g., Martin Lipton \& Steven A. Rosenblum, A New System of Corporate Governance: The Quinquennial Election of Directors, 58 U. CHI. L. REV. 187, 205-13 (1991) (discussing the common focus on short-term incentives over long-term investments).

${ }^{46}$ See supra note 27.

${ }^{47}$ See Ehud Kamar, Shareholder Litigation Under Indeterminate Corporate Law, 66 U. CHI. L. REv. 887, 892-96 (1999) (discussing how legal indeterminacy causes cautious business decisionmaking).

${ }^{48}$ Cf. Robert Parrino. CEO Tumover and Outside Succession: A Cross-Sectional 
performing manager may find that she is forced to leave her present position and must look for another one. And even if not forced to leave, a manager may want to depart voluntarily to get a better job. To the extent that a manager's future employment opportunities are related to how well she performs in her present job, concern over such opportunities creates incentives for high-quality management. ${ }^{\text {t9 }}$

\section{E. Social-Status-Related Incentives}

The way in which a manager runs her company may also affect her power, prestige, and status. For example, a manager of a wellperforming company may earn various forms of public recognitionsuch as being described as "[ $t]$ he best CEO on Earth" one of "America's Most Admired Companies" — and become more powerful. Similarly, most managers would be embarrassed if their companies became entangled in major scandals. As many managers value power, prestige, and status, and want to avoid embarrassment, social-status-related incentives may affect their job performance.

\section{F. Internalized Incentives (a.k.a. Preferences)}

Finally, internalized incentives affect how a manager runs her company. A manager, for example, may work hard because she enjoys it or would feel guilty if she did not. Another may, for similar reasons, run the company in a socially responsible manner. Yet a third may run the company to indulge in her preference for foreign travel and luxury hotels.

Internalized incentives are ultimately a form of preferences. Some managerial preferences may be consistent with, and conducive to, running the company well. Many other managerial preferences, however, detract from having the company run well. The other incentives described above can then be used to align shareholder and manager interests.

Analysis, 46 J. FIN. ECON. 165, 184 (1997) (finding that poorly performing companies are more likely to hire a CEO replacement from outside the firm).

"Se, e.g., Anup Agrawal \& Ralph A. Walking, Executive Careers and Compensation Surrounding Takeover Bids, $49 \mathrm{~J}$. FIN. 985, 986 (1994) (finding that CEOs of target companies who lose their jobs generally fail to find another executive position in a public corporation within three years after the bid).

Andy' Serwer, There's Something About Cisco, ForTune, May 15, 2000, at 114 (asking the cover page question of whether Cisco's CEO is "[ $t]$ he best CEO on Earth").

$\because$ Geoffrey Colvin, America's Most Admired Companies, FORTUNE, Feb. 21, 2000, at 108. 
As this brief sketch demonstrates, multiple types of incentives influence managerial behavior. The various types of incentives have different relations to corporate law. Liability-regime-related incentives derive directly from rights created by corporate law. I will therefore not further discuss their relation to norms, which exclude legal commands, even though norms may reinforce liability-regime-related incentives.

Similarly, compensation-related and job-preservation-related incentives derive from the power structure established by corporate law: the power of directors to run the company, which includes the power to select and compensate officers, and the power of shareholders to elect directors. With respect to these incentives, therefore, corporate law and something else interact. In the next Part, I will analyze whether this "something else" is norms.

The remaining incentives lie largely outside the scope of corporate law. Future-employment-related incentives would appear to be driven primarily by third-party self-protective enforcement and thus do not constitute norms. Social-status-related incentives, on the other hand, are strongly related to third-party punitive enforcement; likewise, internalized incentives may well include internalized norms. The relation of norms to these incentive mechanisms is more fully explored in Part IV.

\section{NORMS AND CORPORATE POWERS}

This Part addresses whether norms affect the two incentive structures relating to the powers created by corporate law: executive compensation-related to the board's power over corporate property-and job preservation-related to the board's power over corporate property and the shareholders' power to replace directors.

The principal focus of my analysis is on whether norms affect the manner in which boards design the executive compensation system. Executive compensation falls, to a large extent, in the power domain of outside directors who, unlike the corporate officers who serve on the board of their company, often have no substantial financial interest in either the fortunes of the company or in retaining their board seats. Moreover, in the area of executive compensation, fiduciary duties impose few, if any, meaningful constraints on outside 
directors. ${ }^{52}$ Given the absence of strong financial incentives and of liability concerns, norms may well influence how outside directors design the executive compensation scheme.

I first describe several common practices in the compensation of U.S. executives. Then, I consider whether "norms" account for the prevalence of these practices. After discussing executive compensation, I briefly address the relation between norms and director replacement.

\section{A. Executive Compensation}

In examining the compensation scheme for the top managers of publicly traded U.S. corporations, it is easy to identify numerous patterns: top executives earn a lot, with the CEO earning the most; the orerall compensation scheme has several components, including a fixed salary, a bonus plan, and a stock option plan; compensation is negotiated between the executive and a compensation committee; "golden parachutes" protect top executives against hostile takeovers; and so on.

It would not be an efficient use of space to provide an exhaustive examination of each of these patterns. Thus, for purposes of this Article, I limit my discussion to two patterns, chosen because of their economic significance and because they are not, to the same extent, present in public corporations in other industrialized countries: the high overall compensation levels and the common use of stock options to remunerate executives. ${ }^{33}$

$\because$ In this regard, outside director decisions regarding executive compensation differ markedly from decisions to approve transactions in which one or more managers have a financial interest-transactions that are intensely scrutinized under fiduciary duty law, leaving less room for norms. See Mark A. Clawson \& Thomas C. Klein, Indexrd Stock Options: A Proposal for Compensation Commensurate with Performance, 3 STIN. J.L. Bus. \& FIN. 31, 38 (1997) ("[E]xecutive compensation is not a matter conducive to judicial oversight."); Charles M. Elson, Executive Overcompensation-A Brrard-Bast'd Solution, 34 B.C. L. REv. 937, 959-62 (1993) (reviewing case law and concluding that "courts have been highly reluctant to involve themselves in compensation disputes"); Edward M. Iacobucci, The Effects of Disclosure on Executive Comperzsation, 48 U. TORONTO L.J. 489, 495 (1998) ("[C]ourts are loathe to intervene in matters of executive compensation.").

The latter fact may make it more likely that these patterns are linked to norms, which connote context and culture specificity, than to economic factors, which tend to be more unirersal. See Ellickson, supra note 3, at 177 (noting the special significance of norms to close-knit groups). Several other patterns are probably attributable to legal rules. Federal tax law, for example, creates incentives for companies to use compensation committees, Perry \& Zenner, supra note 40 , at 129 , and the vibrant 


\section{The Level of Executive Compensation}

Top executives in U.S. public companies earn a lot. This is true in absolute terms as well as in comparison to salaries of workers, of top executives in other countries, and of top U.S. executives in the past.

Consider the following data. In 1997, the median total compensation for a CEO exceeded $\$ 3$ million. ${ }^{54}$ Between 1992 and 1998 , CEO compensation more than doubled while total employee compensation increased by only $20 \% .^{55}$ By 1998, CEOs of large companies received compensation that was 419 times as high as the compensation of their labor force. ${ }^{56}$ In the not-so-distant past of the early 1980 s, that ratio was only 42 to $1 .^{57}$ Foreign executives do not earn nearly as much as their U.S. colleagues. In the mid-1990s, CEO compensation in the United States was about twice as high as the compensation received by CEOs of similar German, British, or French companies. ${ }^{58}$ These cross-country differences are particularly evident when a foreign company acquires a U.S. company. When the German company Daimler-Benz acquired Chrysler in 1997, for example, the top five Chrysler managers together earned $\$ 50$ million, while the top ten Daimler-Benz executives made a measly $\$ 11$ million. ${ }^{59}$

That managers of large companies earn high wages is not remarkable. Why U.S. managers should earn quite as much as they do, so much more than they did in the past, and so much more than their counterparts in other countries do, however, may be less obvious.

Commentators have proposed various explanations for the level of executive pay. For some, the high level of executive pay is purely the result of market forces; companies competing for rare executive talent raise the compensation level for the chosen few. ${ }^{60}$ Consistent with

market for corporate control and the substantial discretion of directors to block unsolicited takeovers may make golden parachutes a desirable component of a compensation package.

${ }^{54}$ The Boss's Pay, WALL ST. J., Apr. 9, 1998, at R13.

${ }^{55}$ Perry \& Zenner, supra note 40, at 123-24.

${ }^{56}$ Tim Smart, Pay Gap Between Workers, Execs Widens in '90s, ANN ARBOR TIMES, Aug. 30,1999 , at A12.

${ }_{58}^{57}$ John A. Byrne, The Flap over Executive Pay, Bus. WK., May 6, 1991, at $90,95$.

58 Tara Parker-Pope, So Far Away, WALL ST. J., Apr. 11, 1996, at RI2.

59 Greg Steinmetz \& Gregory L. White, Sticker Shock: DaimlerChrysler is an Collision Course over Executive Pay, WALL ST. J. EUR., May 26, 1998, at 1.

${ }^{60}$ See Daniel R. Fischel, The Corporate Governance Movement, 35 VAND. L. REv. 1259, 1283 (1982) ("[M]arket constraints ... may be more effective in setting salaries than a committee of uninformed independent directors."); Robert Thomas, Is Comporate 
that theory, new CEOs recruited from outside the firm, an instance where market forces would presumably be strongest, are paid significantly more than CEOs recruited internally. ${ }^{\text {it }}$ While there is probably some truth to this theory, ${ }^{62}$ it fails to explain why compensation levels differ across countries. Multinational companies, presumably, compete for managers internationally. Why then should U.S. companies pay higher compensation than otherwise similar companies in other countries?

Alternatively, as Lucian Bebchuk and David Walker have recently argued, the high level of executive pay may be due to the influence that the CEO holds over the board of directors. ${ }^{63}$ Studies suggest that CEOs have a significant impact on the selection of their fellow board members," and there is some evidence that powerful CEOs receive more generous compensation than their less autocratic counterparts. ${ }^{65}$ This CEO domination theory may also be easier to reconcile with the

Extrutizt Compensation Excessive?, in THE ATTACK ON CORPORATE AMERICA 276, 278 (M. Bruce Johnson ed., 1978) ("Competition among corporations... sets the level of executive compensation."); Nicholas Wolfson, A Critique of Corporate Law, 34 U. MLAMI L. REV. 959, 975-78 (1980) (noting that "excessive" compensation is eliminated by market forces, including competition for executive positions).

"Ste John R. Deckop, Determinants of Chief Executive Compensation, 41 INDus. \& LAB. REL. REV. 215, 225 (1988) (noting that the difference in compensation was about $\$ 100,000)$.

"It Se MlarlanNe Bertrand \& Sendhil Mullainathan, Do CEOs Set Their OWN PAYY THE ONES WITHOUT PRINCIPAL Do 21-22 (Nat'l Bureau of Econ. Research, Working Paper No. 7604, 2000) (concluding that in well-governed firms, pay contracts give CEOs incentives to maximize shareholder wealth, while in poorly governed firms, CEOs capture the pay process so that they set their own pay), available at http://www.nber.org/papers/w7604.

"Se Lucian Arye Bebchuk \& David Walker, Executive Compensation in America: Optimal Contracting or Extracting Rents? (unpublished manuscript, on file with author); see also Elson, supra note 52, at 974-76 (discussing the phenomenon of management capture of corporate boards).

${ }^{14}$ Perry \& Zenner, supra note 40, at 135-36.

".." Sie John E. Core et al., Corporate Governance, Chïf Executive Officer Compensation, and Firm Performance, 51 J. FIN. ECON. 371, 372-73 (1999) (finding that CEO compensation is higher when the CEO is also the chairman of the board, when the board is larger, or when the outside directors are older or very busy). But see Catherine M. Daily et al., Compensation Committee Composition as a Determinant of CEO Compensation, 41 ACMD. MGMT. J. 209, 214 (1998) (failing to find evidence that the presence of captured directors or other CEOs on compensation committees results in higher CEO pay); Ronald C. Anderson \& John M. Bizjak, An Empirical Examination of the Role of the CEO and the Compensation Committee in Structuring Executive Pay 16-18 (2000) (unpublished manuscript, on file wih author) (finding no correlation between the presence of a CEO on the compensation committee and executive pay, after accounting for ownership structure), available at http://papers.ssrn.com/ paper.taf?abstract_id=22085I. 
fact that executive salary levels differ across countries; the influence of the CEO over board members may differ systematically from one country to another. ${ }^{66}$ On the other hand, the CEO domination theory does not explain why U.S. salaries have risen so sharply over the last ten years. During this period, by all accounts, investors have become more powerful and managers have become correspondingly less powerful, suggesting that the degree of overcompensation should have declined. ${ }^{67}$

Mark Loewenstein provides at least a partial answer to both the presence of cross-country differences in pay and the recent surge in U.S. compensation levels. He argues that both phenomena are due jointly to the common use of stock-price-related compensation in the United States and the substantial increase in stock prices of U.S. companies. ${ }^{68}$ Indeed, while average salaries and bonuses have doubled from 1980 to 1994, the value of option grants has risen by almost $700 \%{ }^{69}$ This, of course, just shifts the focus of the inquiry to why stock options are more prevalent in the United States than in other countries-a topic I take up in the next Part. But even after taking account of the effect of stock options, a substantial gap remains between U.S. and non-U.S. compensation levels. According to a recent study, even ignoring stock options, executive salaries in the United States are twenty percent above those in the United Kingdom and more than twice those in France. ${ }^{70}$ Yet if overall compensation were equivalent, one would expect the non-stock-option component

65 See Mark J. Loewenstein, The Conundrum of Executive Compensation, 35 WAKE FOREST L. REV. 1, 9 (suggesting that board members in other countries monitor executives more closely than they do in the U.S.); Bebchuk \& Walker, supra note 63.

${ }^{67}$ See, e.g., Kevin F. Hallock, Reciprocally Interlacking Boards of Directors and Executive Compensation, 32 J. FIN. \& QUANTITATIVE ANALYSIS 331, 340 (1997) (finding that the increased compensation of CEOs whose board contains a reciprocally interlocked CEO of another company was higher in the 1970s than in the early 1990s); Loewenstein, supra note 66, at 15 (noting the increased independence of board members); Perry \& Zenner, supra note 40 , at 130 (concluding that "directors may have become more vigilant monitors of CEOs"); Anil Shivdasani \& David Yermack, CEO Involvement in the Selection of New Board Members: An Empirical Analysis, 54 J. FIN. 1829, 1831 (1999) (reporting that the influence of CEOs over board members has declined); Randall $\mathrm{S}$. Thomas \& Kenneth J. Martin, The Effect of Shareholder Proposals on Executive Compensation, 67 U. CIN. L. REV. 1021, 1035 (1999) (reporting increased activism by institutional investors with respect to executive pay).

68 Loewenstein, supra note 66 , at 4-5.

${ }^{69}$ See Thomas \& Martin, supra note 67, at 1029; see also Perry \& Zenner, supra note 40 , at 124 (reporting that, from 1992 to 1998 , salaries increased by $29 \%$, bonuses by $99 \%$, and stock and stock option grants by $335 \%$ ).

70 Loewenstein, supra note 66, at 3 n.6. 
in the compensation of foreign executives to exceed substantially the non-stock-option component in the compensation of U.S. executives.

Cultural and regulatory factors have also been used to explain cross-country differences. Reportedly, for example, "cultural" and "social" reasons prevent Daimler-Benz executives from raising their compensation to Chrysler levels." Also, high marginal tax rates in Europe and Japan may impose a "tax obstacle" to high salaries. ${ }^{72}$ It is noteworthy, in this regard, that nontaxed perquisites is the only category of pay in which European CEOs outpace their U.S. counterparts $^{73}$ and that the surge in U.S. compensation levels coincided with a substantial decline in marginal tax rates. ${ }^{74}$

Finally, the availability in the United States of information on executive compensation practices, which exposes the high compensation of other CEOs, may have caused a ratcheting up effect in U.S. compensation levels. ${ }^{25}$ It is well established that compensation committees and their expert consultants consider compensation levels at peer companies in setting their own scheme. ${ }^{76}$ On one hand, compensation data from peer companies may provide only information about the market rate for CEO services. " On the other hand, boards and executives may look to such data for other reasons, such as "keeping up with the Joneses" further pay increases. ${ }^{29}$ In either case, such a process arguably produces strong pressure to raise salaries in companies whose executives earn below average compensation levels without, one

II André, supra note 16 , at 161 n.460.

"Cf. Linda J. Barris, The Overcompensation Problem: A Collective Approach to Controlling Executive Pay, 68 IND. L.J. 59, 62 (1992) (arguing that tax cuts enacted during Reagan's presidency removed the "tax obstacle" to granting large salary increases).

"." Mark J. Loewenstein, Reflections on Executive Compensation and a Modest Proposal fin (Further) Reform, 50 SMUU L. REv. 201, 203 (1996).

'Barris, sufra note 72, at 62.

Iacobucci, supra note 52, at 510-11; Thomas \& Martin, supra note 67, at 1041.

"Srr, $1 . g$., Loewenstein, supra note 66, at 7 (noting that compensation committees rely on salary surveys in setting CEO compensation); Thomas \& Martin, supra note 67 , at 1027; Charles MI. Yablon, Bonus Questions-Executive Compensation in the Era of Pay for Pofformancr, 75 NOTRE DAME L. REV. 271, 276 n.5 (1999) (discussing the role of compensation consultants).

17 Sre lacobucci, sufra note 52, at 511 (noting that the discovery of higher pay by a comparable company may force a lower-paying company to raise salaries or risk losing its executive); Loewenstein, supra note 66, at 7 (noting that relying on pay surveys accommodates firms' important motivational, recruitment, and retention concerns).

is Thomas \& Martin, supra note 67, at 1041.

Iacobucci, supra note 52 , at 510 . 
suspects, equivalent pressure to lower salaries of executives who earn above average compensation, with the result that compensation levels generally rise. ${ }^{80}$

\section{The Use of Stock Options}

Stock options are an important component of executive compensation in the United States. ${ }^{81}$ In 1995, more than two-thirds of public companies compensated their CEOs with stock options. ${ }^{82}$ Among large companies, stock options are even more prevalent. According to a 1996 study, $94 \%$ of the 250 largest companies use stock options as part of their compensation package. ${ }^{83}$ Moreover, stock options account for a substantial portion of executives' total compensation. In 1998, options, on average, amounted to $35 \%$ of a CEO's compensation in public companies and $38 \%$ of the compensation of CEOs of S\&P 500 companies. ${ }^{84}$

The common use of stock options is of relatively recent vintage. In 1980, less than one-third of U.S. CEOs held stock options. ${ }^{85}$ Even by 1985 , only $8 \%$ of CEO compensation consisted of options. ${ }^{86}$ Commentators attribute the recent increase to several developments. In 1993, the tax law was changed to disallow deductions for executive compensation in excess of $\$ 1$ million unless the compensation was performance-related. $^{87}$ Moreover, investors pushed to make executive compensation more sensitive to performance. ${ }^{88}$ Compared to other incentive compensation schemes, stock options have the advantages that their value correlates with what investors care most about, that

${ }^{80}$ Kevin J. Murphy, Executive Compensation, in 3B HANDBOOK OF LABOR ECONOMICS 2485 (Orley Ashenfelter \& David Card eds., 1999) (noting that a salary in the fiftieth to seventy-fifth percentile is regarded as competitive).

${ }^{81}$ See generally Stabile, supra note 38 , at 233-36 (discussing incentive compensation).

${ }^{82}$ Perry \& Zenner, supra note 40 , at 129-30.

${ }^{83}$ Clawson \& Klein, supra note 52, at 42.

${ }^{84}$ Perry \& Zenner, supra note 40 , at 131 .

${ }^{85}$ Thomas \& Martin, supra note 67, at 1029.

${ }^{86}$ Barris, supra note 72, at 64.

${ }^{87}$ Perry \& Zenner, supra note 40, at 129.

88 See, e.g., Loewenstein, supra note 66 , at 8 (arguing that increased use of options is due to demands that CEO compensation be more closely linked to shareholder returns); Kevin J. Murphy, Politics, Economics, and Executive Compensation, 63 U. CIN. L. REV. 713, 715 (1995) (“[M] ost shareholder criticisms of CEO pay have stressed the lack of meaningful rewards for superior performance...."); Yablon, supra note 76, at 27980 (discussing attempts to structure executive compensation so as "to provide incentives for shareholder wealth maximization"). 
they are relatively objective and nonmanipulable, ${ }^{59}$ and that they are easy to design and understand." Stock options also have the perceived benefit of not resulting in an accounting expense if they are not "in the money" when awarded. ${ }^{91}$ Moreover, proponents of the CEO domination theory argue that stock options assist managers in camouflaging the fact that they receive excessive compensation."

Options have indeed increased the performance sensitivity of executive pay," although some commentators doubt that they have resulted in improved performance. ${ }^{94}$ Commentators have also argued that so-called indexed or performance stock options-the exercise price of which is adjusted for changes in a broad market index or a more narrow industry index-would create superior incentives to regular stock options. ${ }^{9.5}$ At least up to now, however, such options are rare-possibly because, unlike regular options, they would result in an accounting expense when exercised. ${ }^{96}$

"Cf. Paul M. Healy, The Effect of Bonus Schemes on Accounting Decisions, 7 J. Accr. \& ECON. 85 (1985) (presenting empirical evidence that managers manipulate accounting figures to increase bonuses); Murphy, supra note 80 (noting the dangers of manipulating standards used in bonus plans). But of. Stabile, supra note 38, at 256 (noting that managers can manipulate the value of stock options by reducing dividends).

"'t But sep Lisa K. Meulbroek, The Efficiency of Equity-Linked Compensation: Understanding the Full Cost of Awarding Executive Stock Options (Harvard Bus. Sch., Working Paper No. 00-056, 2000) (unpublished manuscript, on file with author) (noting the substantial real cost of stock options, consisting of the difference between the market value of options and the value placed by managers on the options), http://www.hbs.edu/dor/papers2/9900/00-056.pdf.

"Se' Stabile, supra note 38, at 276-78 ("Stock options are the only type of compensation that generate an expense that is deductible for tax purposes but that does not have to be expensed for financial accounting purposes.").

"I Bebchuk \& Walker, supra note 63.

'.3 Sir Brian J. Hall \& Jeffrey B. Liebman, Are CEOs Really Paid Like Bureaucrats?, 113 Q. J. ECON. 653,685 (1998) (finding that median pay for performance elasticity has more than tripled).

"Stabile, supra note 38 , at $239-41$ (surveying studies and finding their results inconclusive).

Str Clawson \& Klein, supra note 52, at 33 ("[C]hanges in the value of compensatory options should be rationally related to performance...."); Shane A. Johnson \& Yisong S. Tian, Indexed Executive Stock Options, 57 J. FN. ECoN. 35 (2000) (positing that indexed stock options "result in more efficient incentive contracts"); Stabile, supra note 38 , at 274 ("[E]quity theory tells us that for options to function as a means of incentive, compensation received from them must be truly related to performance ...."); Bebchuk \& Walker, supra note 63.

"Murphy, supra note 80 , at 17 (finding that only one of over 1000 firms in the sample used indexed options); Stabile, supra note 38 , at 277-78. In the United Kingdom, by contrast, the use of regular stock option plans has declined in favor of stock-based performance plans based on relative stock price performance. Murphy, 
Finally, stock options are much less common at non-U.S. companies. $^{97} \quad$ Until 1996, for example, no German company had awarded stock options to its executives. ${ }^{98}$ Stock options are also an immaterial component of managerial compensation in Argentina, Australia, Belgium, Italy, Japan, Mexico, Spain, Sweden, Switzerland, and Venezuela. ${ }^{99}$ And even in countries in which stock options are used-such as Brazil, Canada, France, Hong Kong, the Netherlands, and the United Kingdom-they account for a smaller percentage of CEO compensation than they do in the United States. ${ }^{\text {I't' }}$ As explanation, commentators have cited legal uncertainty, ${ }^{101}$ unfavorable tax laws, ${ }^{102}$ cultural factors, ${ }^{103}$ labor opposition, ${ }^{104}$ and the presence of alternative incentive devices. ${ }^{105}$ Even outside the United States, however, the use of stock options is gradually increasing."

\section{Norms and Executive Compensation}

Whether any pattern of behavior is attributable to norms depends on the factors that account for that behavior. To the extent that high pay and options are market-driven devices to attract and provide incentives to top executives, or are responses to tax laws or accounting rules, economic and regulatory incentives, ${ }^{107}$ rather than norms, would

supra note 80 , at 9 n.15.

${ }^{97}$ Loewenstein, supra note 66 , at 5 ("[S]tock options have not been common overseas."); Michael E. Porter, Capital Disadvantage: America's Failing Capital Investment System, HARV. BUS. REV., Sept.-Oct. 1992, at 65, $71-72$ (noting that compensation of Japanese executives is not related to stock prices).

${ }_{98}$ See André, supra note 16, at 161-62 (noting that Deutsche Bank and DaimlerBenz were the first two German companies to create stock options).

${ }^{99}$ Murphy, supra note 80.

${ }^{100} \mathrm{Id}$.

101 See André, supra note 16, at 162 (citing the "nearly unprecedented split" regarding legal authorization); Murphy, supra note 80, at 8-9 (reporting that until 1997, executive stock options were illegal in Japan).

${ }_{102}$ Loewenstein, supra note 66, at 5.

${ }^{103}$ See André, supra note 16, at 162 (noting a common German perception of options as an Anglo-Saxon invention); Porter, supra note 97, at 70-72 (comparing cultural factors).

${ }^{104}$ André, supra note 16, at 162.

${ }^{105}$ Loewenstein, supra note 66, at 9; see also Perry \& Zenner, supra note 40 , at 136 (finding that U.S. firms use less equity-based compensation when other incentives exist).

${ }^{106}$ See Loewenstein, supra note 66, at 5 n.20; Murphy, supra note 80 , at 9 ("[I]nterest in stock options is exploding elsewhere in the Pacific Rim and in Europe and Latin America.").

${ }^{107}$ Even though financial accounting rules are initially promulgated by the 
explain these features. To the extent CEO domination of the board accounts for high compensation levels and the use of regular stock options, however, a further analysis is necessary to determine whether norms contribute to the ability of a CEO to dominate the board.

The principal factor enabling CEOs to dominate boards is undoubtedly the dispersion of shareholdings that gives rise to the separation of ownership and control. The collective action problem makes it difficult for dispersed shareholders to monitor management and thus creates a power vacuum that a CEO may fill. Thus, the potential for CEO domination results from the underlying economic ownership structure of public companies.

Moreover, CEOs have stronger economic incentives to pursue board domination than do many outside directors to resist domination. CEOs prefer deferential boards to assure board approval of CEO-favored policies in general and policies in which the CEO has a personal stake, such as executive hiring and compensation, in particular. CEOs can therefore be expected to invest time and effort in dominating boards. CEOs are helped on this front by the fact that they are more knowledgeable about corporate affairs than outside board members and that they typically receive automatic support from subordinate officers who occupy board seats. Outside directors, by contrast, have low financial stakes in the company or in retaining their board seats, are less knowledgeable about corporate affairs, and have no natural body of fellow directors on whose support they can count. Accordingly, they can be expected to invest little time and effort in resisting CEO domination.

A related factor contributing to a CEO's ability to dominate boards is the legal regulatory structure that grants incumbent board members exclusive access to the proxy machinery for board elections and highly preferred access to the corporate treasury to fund election expenses. This structure contributes to the largely self-perpetuating nature of corporate boards, in which incumbent board members propose the slate of directors and shareholders usually elect the incumbent board's nominees. Thus, once in control of the board, a CEO can relatively easily retain control by assuring the selection of allies to the board or even by having an occasional antagonist removed from the board.

Financial Accounting Standards Board, a nongovernmental body, it is SEC rules that require companies to abide by these standards. See, e.g., SEC Regulation S-X, 17 C.F.R. $\$ 210.2-02$ (c) (2000) (requiring the accountants' report to opine on the consistency of financial statements with generally accepted accounting principles). 
While these economic and legal factors may well account for the prevailing degree of CEO domination, Bebchuk and Walker also suggest that norms of reciprocity, authority, and similarity ${ }^{108}$ constrain outside board members from scrutinizing executive compensation awards. ${ }^{109}$ But even though norms of that sort may well be held among outside directors, their significance to executive compensation is limited. For one, these norms do not ipso facto result in high compensation awards. If, for example, outside board members were selected by shareholder groups, earned moderate income, and looked to a director with a large equity stake in the company for guidance, norms of reciprocity, authority, and similarity could well result in increased scrutiny of compensation awards. It is only if the CEO selects board members, who tend to earn high income, that norms of reciprocity, authority, and similarity reduce such scrutiny.

Second, an important fact in increasing compliance with such norms is the ability to select persons as directors who subscribe to these norms. Thus, if these directorial norms exist, it may not be so much that outside directors abide by them because they are outside directors, but rather that outside directors are selected as outside directors because they abide by them.

In both of these respects, therefore, the relation between norms and executive compensation depends on the process through which outside directors are selected, and specifically on the relative influence of the CEO and shareholders in this process. And economic and legal factors, rather than normative ones, largely determine this relative influence.

A stronger argument for the influence of norms, also advanced by Bebchuk and Walker, is that an "outrage constraint" limits the compensation awarded to CEOs. ${ }^{10}$ What accounts for this outrage constraint is that outside directors are reluctant to approve a compensation plan that would embarrass them or compromise their reputations. ${ }^{111}$ Even with respect to this outrage constraint, however, norms with respect to U.S. compensation awards seem, in

${ }^{108}$ Bebchuk and Walker also argue that questioning CEO compensation runs counter to the "support or fire" model of the board. It is, however, unclear whether this model is a social norm or just a description of how rational outside directors act. See Bebchuk \& Walker, supra note 63 (suggesting that a reluctance to challenge the CEO may reflect a logical conclusion that little can be gained from doing so).

\footnotetext{
${ }^{109} I d$.

${ }^{110}$ Id. at 28-31.

ili Id. at 29 .
} 
international comparison, weak. Thus, it has been argued that social and cultural norms constraining mega-compensation kick in much earlier in Europe than in the United States. For instance, DaimlerBenz claimed that social and cultural reasons precluded it from raising the salaries of its top German executives to U.S. levels. ${ }^{\text {112 }}$

To sum up, plausible arguments can be made that norms have some impact on executive compensation. A CEO may use norms of reciprocity, authority, and similarity, to which outside directors subscribe, to obtain higher compensation, and a counterveiling outrage constraint may limit how much compensation outside directors are willing to grant to a CEO. Even in this area, however, economic and legal factors predominate. To the extent that CEOs indeed dominate boards, this is principally due to the economic reality of share dispersion, the incentive disparity between CEOs and outside board members, and the legal regulatory structure that contributes to self-perpetuating boards.

\section{B. Director Replacement}

While norms have some role in executive compensation, their relative significance for shareholder decisions to replace directors is negligible. ${ }^{11}$ For one, the legal regulation of shareholders' powers is much more detailed than the broad delegation of operational powers to management. Legal rules, for example, circumscribe shareholders' power to replace directors by regulating whether shareholders can replace directors without cause, regulating whether shareholders can convene a shareholders meeting or act outside of a meeting, and limiting the length of a director's term. ${ }^{114}$ They give boards the power to implement poison pills without the approval of shareholders and

112. André, supra note 16 , at 161 n.460.

11. Whether norms affect the board's exercise of its power to fire executives is a separate inquiry. I am, however, not aware of any major regularities in the exercise of this power beyond the obvious one that successful CEOs are rarely fired. For a summary of studies on CEO turnover and corporate performance, see Murphy, supra note 80. In any case, the factors affecting the exercise of that power are likely to resemble those affecting executive compensation awards. See supra Part III.A.3 (enumerating factors such as the dispersion of shareholdings and the legal regulatory structure that affect executive compensation awards).

${ }^{114}$ Similarly, legal rules determine to what extent managers have the power to institute governance changes without shareholder approval, to what extent shareholders have the power to institute governance changes without the approval of managers, and to what extent governance changes can be instituted only with the approval of shareholders and managers. 
have sanctioned pills that, unless redeemed, pose economically insurmountable barriers to a hostile acquisition. ${ }^{115}$ At the same time, legal rules deny boards the power to adopt "dead-hand" pills that can only be redeemed by directors that were incumbents at the time of a hostile bid, ${ }^{116}$ and they impose a set of special fiduciary duties that directors have to comply with when faced with a proxy contest or a hostile tender offer. ${ }^{117}$

Within these legal constraints, economic factors largely determine actions by shareholders, challengers, and incumbents. Proxy contests, for instance, rarely result in a change of $\operatorname{control}^{118}$ because waging a proxy contest is costly; ${ }^{119}$ because challengers are not reimbursed for the contest's expenses unless they obtain control, whereas the company bears the incumbent's expenses regardless of the outcome; ${ }^{120}$ because the gains a challenger may obtain from increasing firm value through traditional proxy contests are limited; ${ }^{121}$ and because shareholders are rationally suspicious of a challenger's motives in waging the proxy contest. ${ }^{122}$

${ }^{115}$ See Paramount Communications, Inc. v. Time, Inc., 571 A.2d 1140 (Del. 1989) (giving the board great discretion in refusing to redeem the poison pill); Moran v. Household Int'l, 500 A.2d 1346 (Del. 1985) (upholding the general validity of the poison pill).

${ }^{116}$ Quickturn Design Sys., Inc. v. Shapiro, 721 A.2d 1281 (Del. 1998) (holding all dead-hand pills invalid).

${ }^{117}$ MacAndrews \& Forbes Holdings, Inc. v. Revlon, Inc., 501 A.2d 1239 (Del. 1985) (holding that the duty of the board when selling the company is to obtain the best price); Unocal Corp. v. Mesa Petroleum Co., 493 A.2d 946 (Del. 1985) (subjecting takeover defenses to heightened scrutiny); Blasius Indus., Inc. v. Atlas Corp., 564 A.2d 651, 658-63 (Del. Ch. 1988) (elaborating on the fiduciary duty of the board in a proxy contest).

${ }^{118}$ Peter Dodd \& Jerold B. Warner, On Corporate Governance: A Study of Proxy Contests, 11 J. FIN. ECON. 401, 407-411 (1983) (finding that in a sample of ninety-six contests unrelated to takeover bids between 1962 and 1978, eighteen resulted in a change of control).

${ }^{199}$ See Lucian Arye Bebchuk \& Marcel Kahan, A Framework for Analyzing Legal Policy Towards Proxy Contests, 78 CAL. L. REv. 1071, 1085-87 (1990) (discussing the rarious types of costs involved in a proxy contest).

${ }^{120}$ See Waterside Partners v. C. Brewer \& Co., 739 A.2d 768 (Del. 1999) (holding that the unitholder group that waged a successful proxy campaign against a merger is not entitled to reimbursement of attorneys' fees); Bebchuk \& Kahan, supra note 119, at 1106-10 (discussing legal rules and practice on compensation of expenses).

${ }^{121}$ In principle, challengers can benefit from the contest in two ways: by increasing the value of their existing equity through, say, improved management or by obtaining private benefits from controlling the company. Bebchuk \& Kahan, supra note 119 , at 1091-93. Since challengers' existing equity stakes are often small, the benefits they would derive from raising the value of the company is limited.

${ }^{122}$ Challengers, at least implicitly, chose to seek control through a traditional 
Norms have arguably been more important in the past. Bob Cooter and Mel Eisenberg have suggested that the failure of blue-chip corporations, prior to the mid-1970s, to make hostile tender offers is attributable to norms. ${ }^{123}$ I have not investigated this assertion and have some reservations about its historical accuracy. But whatever the historical truth, the fact that norms may have been significant in the past does not indicate that they are significant today. Indeed, Cooter and Eisenberg do not claim that norms constrain or, for that matter, induce hostile bids today. ${ }^{124}$ At least in the present, therefore, there is no substantial role for norms in the area of director replacement.

\section{NORMS AND EXTERNAL INCENTIVES}

In this Part, I examine the relation of norms to two aspects of the incentive structure external to corporate law: social-status-related incentives and internalized incentives.

Rules that are sanctioned through a heightened or lessened social status lie at the core of many norm definitions. Bad gossip, for example, is a major norm enforcement device that Ellickson identifies in a close-up study of dispute resolution in Shasta County. ${ }^{125}$ And McAdams's theory specifically ties norm compliance to social esteem. ${ }^{126}$ Moreover, the content of rules enforced through the

proxy contest rather than through a hostile bid. A traditional proxy contest is relatively more attractive for challengers motivated by private control benefits, while a hostile bid would be relatively more attractive for challengers motivated by increasing company value. See Steven Lipin, More Potent Weapons Dwell in Takeover Arsenal, Wall ST. J., Sept. 7, 1995, at C1 (noting shareholder reluctance to vote for a change in control without an accompanying bid for the company's shares). Moreover, most high-quality managers would rather make better use of their time-including running their own companies and having them stage hostile bids-than institute a traditional proxy contest. That a manager is participating in a proxy contest just sends a negative signal about her quality.

${ }_{12.4}$ Cooter \& Eisenberg, supra note 1, at 1718.

i2* In contrast, Henry' Hansmann suggested to me that there is a present-day norm of productivity that contributes to hostile takeovers. While I agree that productivity is valued in present-day society, I am less sure that it is valued as a norm-that is either enforced by third parties bestowing social status on productive members of society or that has become an internalized value-or an ideology-that is based on the belief that one becomes richer by being more productive and on materialistic preferences where financial wealth becomes relatively more important to increase one's utilities. Even to the extent that productivity is a norm, I am uncertain how much it contributes to hostile takeovers.

${ }_{125}$ Spe Ellickson, supra note 3, at 214-15 (describing the practice of spreading truthful negative gossip to pressure cattle trespassers into proper future conduct).

I:' Set ICAdams, supra note 2, at 355-75 (presenting an esteem theory of norms). 
bestowal or withholding of social esteem may well have become internalized. If obtaining social esteem or corresponding internalized preferences significantly affected the overall quality of managerial performance, norms would be an important element in the incentive scheme.

\section{A. Social-Status-Related Incentives}

A conclusive determination of how much the desire for social esteem contributes to managerial quality must await a carefully executed empirical study. My hunch, however, is that it is not much. For one, relative to compensation and job preservation, the desire for social status provides only a weak motivating force for managers. In addition, social status depends on factors other than what the manager does, such as the quality of the executive's communications department, the executive's personality, appearance, and so on. Most importantly, social esteem can accrue to managers for many different types of actions, some of which may even be negatively correlated with high-quality management. A manager, for example, may increase her esteem by devoting her time to public causes, ${ }^{127}$ running a "cool" company, ${ }^{128}$ getting an unusually high salary, ${ }^{129}$ introducing innovative products, ${ }^{130}$ or selling expensive watches. ${ }^{131}$ That there are many ways for managers to enhance their social status, however, does not make social status a more important explanatory variable for managerial behavior. Rather, it means that the motivating force of social status gets diluted. Social-status-related incentives are therefore unlikely to be a substantial factor affecting the overall quality of managerial performance.

A somewhat stronger argument can be made that concern for social status motivates outside directors who, as mentioned, have less of a direct stake in the fortunes of the company. Mel Eisenberg has

${ }^{127}$ See, e.g., Susan Adams, Corporate Communion, FORBES, Apr. 3, 2000, at 82 (describing the charitable activities of former GE executive Edward Morgan).

${ }^{128}$ See, e.g., Julie Creswell et al., Cool Companies 2000, ForTUNE, June 26, 2000, at 98 (featuring thirteen cool companies and their executives).

${ }_{129}$ See, e.g., Kerry A. Dolan, The Age of the $\$ 100$ Million CEO, FORBES, Apr. 3, 2000, at 122-24 (featuring a full size cover page photo of Robert Howe who, in 15 months, earned more than $\$ 500$ million in compensation).

${ }^{130}$ See, e.g., Robyn Meredith, Digital Drive, FORBES, May 29, 2000, at 128 (featuring cutting-edge, e-car technology and highlighting GM CEO Rick Wagoner).

${ }^{131}$ See, e.g., Joshua Levine, Time Is Money, ForbeS, Sept. 18, 2000, at 178, 180 (featuring a cover page photo of watchmaker Christian Bedat). 
recently argued that outside directors, who once passively followed the direction set by the CEO, now adhere to a new norm that requires that they exercise greater care and actively monitor senior executives. ${ }^{1.12}$ While I agree with Eisenberg that monitoring by outside directors has increased, active monitoring by outside directors has not, so far, become regular practice. Moreover, monitoring by outside directors is likely to have increased, to the extent it has, for reasons unrelated to the desire for social esteem. These reasons include the growing importance of institutional investors with significant voting power and professional ties to outside directors and legal rules providing incentives to companies to put more outside directors on their boards. To be sure, the desire for social esteem, including esteem from institutional investors, may also motivate individual outside directors. Overall, however, my guess is that the desire for social esteem from those who desire an active board and from those who prefer a passive board largely cancel each other out, contributing to an uneven practice of some active directors, some passive directors, and many in-between ones.

\section{B. Internalized Incentives}

A final argument I address here relates to the conjecture, recently voiced by Lucian Bebchuk and David Walker, that it is unnecessary to provide incentives for executives to expend effort since "U.S. CEOs are more likely to be workaholics than shirkers." Bebchuk and Walker are correct that U.S. executives are hard working not only because they stand to derive strong financial gains from business success, but rather because they enjoy, or at least do not dislike, hard work. ${ }^{1.44}$ This raises the question of why managers have this preference.

For one, not every preference for hard work can be attributed to

1'2 Eisenberg, supra note 9, at 1278 (describing the change in corporate governance models from a "managing board" to a "monitoring board"). This norm would obviously not be consistent with the CEO domination theory advanced by Bebchuk and Walker in the context of CEO compensation. See supra text accompanying notes $63-67$.

${ }^{13}$ Bebchuk \& Walker, supra note 63.

1.4 Even if Bebchuk and Walker are correct, the other elements of the managerial incentive structure would remain necessary to assure that managers work hard to pursue shareholder interests rather than their own. See Murphy, supra note 89 , at 721 (arguing that many managers value corporate survival over value maximization); Perry \&: Zenner, sufra note 40 , at 142-44 (reviewing studies that suggest that managers make acquisitions in order to raise their salaries). 
norms. Some executives, for example, may have a biological or psychological predisposition towards working hard that is unrelated to norms. Others, by contrast, may have internalized a neo-puritan work ethic, in which hard work is a source of social and self-esteem. This latter group can be said to have a normative internalized incentive for hard work.

It is plausible that persons who subscribe to such a norm of hard work are overrepresented in managerial ranks. In principle, two different explanations could account for this. First, working as a manager may instill a norm of hard work. ${ }^{135}$ In other words, being a manager causes one to subscribe to a norm of hard work. Hard work would then be a true managerial norm. Second, the managerial selection and self-selection process may lead persons who already subscribe to that norm to become managers. ${ }^{136}$ A managerial career would appeal more to persons who like hard work, and those who like hard work are more likely to succeed in it-just as persons who are tall are more likely to try becoming, and to succeed as, professional basketball players. The chain of causation runs in the other direction: being hard working causes one to become a manager. Though hard workers are prevalent among managers, there is no special managerial norm of hard work.

To be sure, even if the second explanation is correct, as I believe it largely is, it is necessary for there to be a sufficient supply of hard workers in the population at large. Norms, which affect that supply, thus have some significance (comparable to the factors of genetics and nutrition in affecting the supply of tall persons who may become basketball players). The key factor, however, is the non-normative managerial selection process that results in the hiring and promotion of hard workers. Thus, even to the extent that an internalized norm of hard work is an important aspect of the incentive scheme, nonnormative factors would largely account for the presence of hard workers in managerial ranks.

\section{GONCLUSION}

Using norms to analyze the corporate structure requires first a

${ }^{135}$ See, e.g., Cooter \& Eisenberg, supra note 1, at 1727 (discussing corporatc "education," which occurs "when the firm voluntarily undertakes programs ... that communicate the firm's norms to its agents").

${ }^{136}$ See id. at 1727-28 (noting that screening and monitoring are two methods in which organizations can employ managers who adhere to norms). 
more precise demarcation of how far the concept of norms extends. Obviously, the further one stretches that concept, the more important norms become. By the same token, however, the further one stretches the concept of norms, the less useful it becomes as an analytical tool. Definitions of norms that include rules that a third party enforces to protect herself-rather than to punish those who violate, or reward those who comply with, a rule-are better analyzed using traditional economic models. Including such rules in the scope of norms would stretch the concept of norms beyond its useful boundaries.

More narrowly, and in my view more properly, defined, norms play a limited role in the corporate governance of contemporary U.S. public corporations. Specifically, norms may affect the executive compensation structure by imposing an "outrage constraint" on grossly excessive awards and by making it somewhat easier for CEOs to dominate boards. An internalized norm of hard work may reduce managerial proclivities to shirk. Even in these respects, however, nonnormative factors largely account for the fact that managers and outside directors who subscribe to the relevant norms hold their respective positions.

Arguably, norms were once more important in the United States, and they may remain more important in other countries. Many norms scholars suggest that norms tend to be most significant in regulating relations in small, socially cohesive groups. To this one may add that the potential for norms compliance is greatest when more high-powered incentive devices are absent. Viewed in this light, the modern public corporation in the United States does not lend itself to norms governance. The relevant decisionmakers in these corporations-managers, outside directors, and shareholders-are not as such members of small and socially cohesive groups, and at least managers and shareholders have substantial financial stakes in how a corporation is run. Maybe, in the days of yore, these groups were smaller and more cohesive, stock options were absent, and hostile takeovers were rare. Maybe then, gentlemen dominated corporate America and enforced on each other the rules of corporate chivalry, and maybe such gentlemen are still powerful in other countries. But whether we like it or not, small, socially cohesive groups are gone from U.S. public corporations and high-powered incentives are here to stay.

In the lead article for an earlier symposium on law and norms, Robert Ellickson, one of the foremost norms scholars, predicted: 
"[T]he newly found appreciation of norms is likely to cause the significant redirection of law and economics."137 My prediction for the field of corporate law is that Ellickson's prediction will not hold true. 